\title{
A novel study on UV protection and antibacterial properties of washed denim garment
}

\author{
Md. Nahid Pervez ${ }^{1,2}$, Md. Anisur Rahman ${ }^{3}$, Liping $\mathrm{Yu}^{4}$ and Yingjie Cai ${ }^{1,5}$ \\ ${ }^{1}$ School of Chemistry and Chemical Engineering, Wuhan Textile University, Wuhan 430073, China \\ ${ }^{2}$ Research Institute of Flexible Materials, School of Textiles \& Design, Heriot-Watt University, Galashiels TD1 3HF, UK \\ ${ }^{3}$ School of Textile Science and Engineering, Wuhan Textile University, Wuhan, 430073, China \\ ${ }^{4}$ Zhejiang Institute of Modern Textile Industry, Shaoxing 312000, China \\ ${ }^{5}$ Hubei Provincial Engineering Laboratory for Clean Production and High Value Utilization of Bio-based Textile Materials, Wuhan Textile \\ University, Wuhan 430073, China
}

\begin{abstract}
On this planet, many investigations are applied to switch conventional chemical cloth techniques via ecopleasant and economically attractive bioprocesses using enzymes. The present study offers an enzymatic washing system using enzyme (Cellzyme SPL H/C) for boosting the ultraviolet and antimicrobial undertaking of denim garments. Experimental results showed that the $4.0 \%$ o.w.f enzyme awareness furnished a greater UPF than the other concentrations and before washed. Results divulge that enzyme (Cellzyme SPL H/C) not handiest preserve the fabric surface from UV degradation but also performed extended degree of antibacterial endeavour in opposition to some species of bacteria that leading to act as a nice antibacterial agent on the denim materials. The enzyme washing healing diminished the skin hairiness and accelerated the skin evenness of the denim fibres as shown by means of SEM measurements.
\end{abstract}

\section{Introduction}

As it is known, denim (jeans) is among the trendiest, dynamic, progressive fabric products and it is the handiest material that can be worn throughout any season [1]. Brands are now watching for more technological, sustainable, and alleviation fabrics and jeans to preserve and give a boost to their progressive line. Now-a-days specific types of systems are applied and washing is known as one of the crucial greatly used finishing healing that has colossal utilization in cloth sectors on account that of creating specific appearance and making trendy and wear at ease garments of the state-of-the-art world [2, 3]. Essentially the most frequently used denim washing methods are enzyme wash, bleach wash, acid wash, usual wash, stone wash, and so forth. Among the many washing methods, enzymatic methods are essentially the most broadly used procedure in industry as a result of its low damaging nature on clothes floor and eco-friendly nature compared to others [4-8]. In enzyme washing, cellulases attack notably surface of the clothes, leaving the interior of the clothes as it is by doing away with the dye gift in the floor layer of clothes [9]. Nonetheless, extraordinary types of materials and finishing remedies are anticipated to have a large impact on sensible characteristics. Aside from the innovations in fabrication, application of useful finishes to clothes, corresponding to UV safety, antimicrobial finish, fragrance conclude and antifungal, add up more value to the top product in the present market situation. Among them UV-security and antimicrobial conclude appeal to much attention in up to date years. As a consequence, purchasers have turn out to be more and more aware of the necessity for sun safety, which is regarding the incidence of solar brought on dermis harm and its relationship with an expanded exposure to UV light. In case of antimicrobial conclude presents the more than a few advantages of controlling the infestation by means of microbes safeguard textiles from staining, discoloration, and fine deterioration and prevents the odour formation [10, 11]. Mainly, finishing is applied for already sewn garments, hence, it is vitally major to know the influence made by way of particular washing on the stitching garment material in an effort to keep the exceptional of a sewing garment.is applied for already sewn garments, therefore, it is very important to know the impact made by particular washing on the sewing garment fabric in order to preserve the quality of a sewing garment.

In this study, the idea of imparting antibacterial property into cotton denim material along with UV protection was involved, aiming to boost aged-regarded denim by means of using cellzyme in washing process which based authors abilities have not ever done before.

\section{Experimental}

\subsection{Materials}


Indigo dyed denim garment used for this experiment is commercially available $100 \%$ cotton, twill weave $(3 / 1)$, construction: 72 (Ends/inch) X 41 (Picks/inch) / 8 Ne (Warp yarn count) X 12 Ne (Weft yarn count). Amylase, Cellzyme SPL H/C was supplied by Jeans Corporation, Australia.

\subsection{Method}

Samples were desized for $15 \mathrm{~min}$ at $70^{\circ} \mathrm{C}, \mathrm{pH}=7$, Liquor to Goods Ratio 1:50, required amount of amylases, soda ash, detergent, anticreasing and desizing agent had been adjusted and then, washed thoroughly. The bathing system was once applied liquor containing acetic acid $(1.0 \mathrm{~g} / 1)$ at $\mathrm{pH}(4-5.5)$ and material to liquor ratio of $1: 30$ at concentration of Cellzyme SPL H/C of (2-6) \% o.w.f at $\left(40-60^{\circ} \mathrm{C}\right)$ temperature for $60 \mathrm{~min}$. The process was once terminated through growing the $\mathrm{pH}$ to 8 and the temperature to $80 \mathrm{oC}$ for $10 \mathrm{~min}$ then washed thoroughly. Finally, garments were treated with cationic softener at $40^{\circ} \mathrm{C}$ for $10 \mathrm{~min}$. Subsequently, clothes were treated with cationic softener at $40^{\circ} \mathrm{C}$ for $10 \mathrm{~min}$. For hydro-extraction procedure, treated denim samples had been squeezed in a laboratory scale hydro-extractor machine at $200 \mathrm{rpm}$ for 4 min and dried in a steam drier at $75^{\circ} \mathrm{C}$ for $40 \mathrm{~min}$.

\subsection{Characterization and functional properties}

Scanning electron microscope (SEM) measurements of the samples were carried out on Hitachi-S 3400 N, (Japan) [12]. The ability of a fabric to block UV light is given by the ultraviolet protection factor (UPF) values. The UPF values are calculated according to AATCC test method 183-2004. The antibacterial activity of enzyme washed denim fabric samples (washed and unwashed) was evaluated qualitatively by using the AATCC-147 method, using Staphylococcus aureus (gram-positive) and Escherichia coli (gram-negative) bacteria.

\section{Results and discussion}

Since the primary venture of the present work is to browsing for the correct cure formulations and stipulations for upgrading and embellishing the UV protective and antibacterial functional houses of washed cotton denim fabrics for producing fabric articles with better defense potential, a large variety of causes were examined. Outcome bought together with their right dialogue follow.

\subsection{UV-Protection}

Researchers showed that ultraviolet radiation (UVR) from the solar would be a principal cause of skin melanoma [13, 14]. The bigger the UPF worth, the longer a person can stay within the sun until the area of epidermis underneath the material turns into red. However, many of the reports have eager about the material parameters with woven materials only, whereas there were few stories regarding denim fabrics. In order to analyse the have an effect on of various solution parameters such as enzyme concentration, temperature and $\mathrm{pH}$ on UPF values is reported in Table 1. Results of UPF measurements of pristine sample just is not good which shows that without any treatment do not have UV protecting potential as their UPF values are round 11.5 $(<15)$ which can not be labeled as just right safety. Nevertheless, enzymatic desized fabric promotes a very good level of protection 20.2 (15-24). However, there is a brilliant develop in UPF values once the materials are washed with enzyme. The washed materials verified superb UV security rating (25-39). In phrases of solution parameters, UPF values of materials have been progressively stronger with enzyme attention increased however after $4 \%$ found low UPF rating. If we take into consideration about effect of temperature, generally speaking, enzyme reaction raises with temperature however it is only activated within a temperature range in which the enzyme constitution keeps steady and unchanged. Beyond this optimum range, the enzyme activity will decrease sharply as the protein structure of enzyme is tangled through thermal agitation. The enzyme activity will slash sharply as the protein structure of enzyme is tangled by means of thermal agitation. Enzyme performs its maximal endeavour at a specific range of $\mathrm{pH}$ values. Deviation of the foremost $\mathrm{pH}$ variety will alter the interior constitution of enzyme as a result of the electrostatic interactions within the enzyme. As a result, the enzyme will not participate in its natural perform [15]. The alterations discovered in UPF values are attributed to material shrinkage which, in flip, leads to reduced porosity of the materials and excessive absorptive potential of the cotton fibre which allows the buildup of enzyme on cotton materials and due to as anticipated, a larger quantity of shrinkage occurred in the cotton materials. Also, the materials thickness was accelerated after enzyme washing treatment, lowering fabrics porosity, producing a closer weave; preventing UVR transmission via the compact material surfaces for this reason multiplied UPF. As we all know, smoother fibre surface reflects extra UV rays and the hydration or moisture content could be one more element accountable for increasing UPF values after enzyme washed [16]. The cellzyme utilized in enzyme washing may just effect in swelling of fibers as a result of accelerated moisture absorption, hence lowering the interstices and increases the imply UPF rating [10], which means treated sample 3 furnished excellent UV safeguard and chosen as the optimized washing conditions.

Table 1. UPF mean values of enzyme washed denim

\begin{tabular}{|c|c|c|c|c|}
\hline Samples & $\begin{array}{c}\text { Enzyme } \\
\text { concentration } \\
(\%)\end{array}$ & $\begin{array}{c}\text { Temperature } \\
\left({ }^{\circ} \mathrm{C}\right)\end{array}$ & $\mathrm{pH}$ & $\begin{array}{c}\text { Mean } \\
\text { UPF }\end{array}$ \\
\hline Pristine & - & - & - & 11.5 \\
\hline Desized & - & - & - & 20.2 \\
\hline Treated 1 & 2 & 40 & 4.2 & 31.2 \\
\hline Treated 2 & 3 & 45 & 4.8 & 33.3 \\
\hline Treated 3 & 4 & 50 & 5.1 & 35.6 \\
\hline Treated 4 & 5 & 55 & 5.3 & 34.7 \\
\hline Treated 5 & 6 & 60 & 5.5 & 34.5 \\
\hline
\end{tabular}




\subsection{Antibacterial activity}

The antibacterial activity of washed fabric used to be evaluated quantitatively with the aid of measuring the number of colonies of gram-positive (S. aureus) and gram-negative (E. coli) bacteria as per the experiment approach mentioned in the experimental part. Results are presented in Table 2. As expected, there used to be no noticeable development of both bacteria on pristine fabric. In addition, there was a development in micro-organism recovered from the pristine material indicating that both strains can use the material as a suitable substrate. It was additionally discovered that enzymatic desized fabric confirmed bacterial growth of around $20 \%$. In terms of solution parameters, the antibacterial endeavour of the handled samples had been evaluated and it was located that with an increase within the awareness of enzyme (up to $4 \%$ ), the bacterial development improved as much as $40 \%$ however after that material showed much less antibacterial activity in opposition to both types of bacteria. This may be due to the improved weight addon $\%$ of the enzyme lively ingredients on the material with growing enzyme awareness. The enhancement in antimicrobial recreation of treated substrate is a direct outcome of utilising an electrochemical mode of motion to penetrate mobile wall of microorganism, thereby inflicting leakage of essential metabolites and bodily disrupting other key phone features on contact to kill it and thoroughly leaching antimicrobial moieties to enter or react chemically with the microorganisms performing as a poison or inhibitor [17].

Table 2. Antibacterial activity of enzyme washed denim

\begin{tabular}{|c|c|c|c|c|}
\hline $\begin{array}{c}\text { Enzyme } \\
\text { concentration } \\
(\%)\end{array}$ & $\begin{array}{c}\text { Temperature } \\
\left({ }^{\circ} \mathrm{C}\right)\end{array}$ & $\mathrm{pH}$ & $\begin{array}{c}\text { S. } \\
\text { aureus }\end{array}$ & E.coli \\
\hline- & - & - & - & - \\
\hline- & - & - & 20 & 21 \\
\hline 2 & 40 & 4.2 & 31 & 32 \\
\hline 3 & 45 & 4.8 & 33 & 34 \\
\hline 4 & 50 & 5.1 & 38 & 40 \\
\hline 5 & 55 & 5.3 & 36 & 37 \\
\hline 6 & 60 & 5.5 & 35 & 38 \\
\hline
\end{tabular}

\subsection{Fibre morphology}

SEM measurements have been applied with a view to be trained the outcome of the enzyme washed on the skin morphology of the fibres. Pristine fabric is smooth and there is no coating and deposition (Figure $1 \mathrm{~d}$ ) and in case of desized fabric (Figure $1 \mathrm{e}$ ) is embedded with tiny particles of sizing agent and the surface of fabric is irregular due to emphasize of sizing agent and waxes have been gently eliminated from the material floor, leaving it intact with applicable whiteness. It may be observed from (Figure $1 \mathrm{f}$ ) that entanglements of fibre surfaces of handled pattern with combination of enzymatic desized and cellzyme are broken not up to handled samples with amylases. This can also be due to lowering of cellzyme activity when mixed with amylase and hydrolytic removal of protruding fibrils and important partitions of the fibres during washing system [18]. Also, which means the cellzyme have not any hazard to enter to the yarn building during the enzymatic processing time to hydrolyse the internal fibers and total regarded that, it may lessen the fiber surface damage.
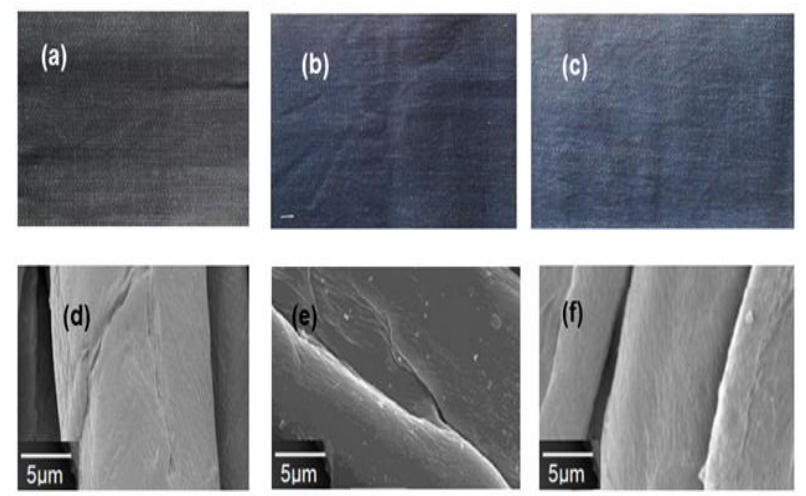

Figure 1. Digital photos of (a) pristine, (b) enzymatic desized and (c) enzyme washed and SEM images of (d) pristine, (e) enzymatic desized and (f) enzyme washed (optimum condition: enzyme concentration 4\%, pH 5.1, temperature $50^{\circ} \mathrm{C}$ )

\subsection{FT-IR analysis}

FT-IR, an apparent acute address was acclimated to study the chemical modification on the surface of fabrics are illustrated in Figure 2. For all samples, a broad band between 3100 and $3700 \mathrm{~cm}^{-1}$, centred on $3360 \mathrm{~cm}^{-1}$, illustrated characteristics of $\mathrm{OH}$ functional groups in cellulose. A strong adsorption band with a maximum at $1030 \mathrm{~cm}^{-1}$ is an aftereffect of the overlapping bands attributed to the functional groups of cellulose, namely the $\mathrm{C}-\mathrm{C}, \mathrm{C}-\mathrm{O}$ and $\mathrm{C}-\mathrm{O}-\mathrm{C}$ stretching vibrations [19]. Some apparent differences observed in the assimilation characteristics in the $900-1100 \mathrm{~cm}^{-1}$ arena of the treated sample with enzyme after the washing. This region is found to be very sensitive to the crystalline as compared to the amorphous structure of the cellulose of denim fabrics since the hydrolysis of $1,4 \beta$-glucosique of the cellulose molecule link breaks the molecule into several pieces (i.e. broadening of the band reflects a higher degree of the disordered structure). Due to the disorder of the cellulose structure is caused by the angle changes around the B-glucosidic linkage and rearrangement of hydrogen bonds [20], a marked increase is shown in intensity. 


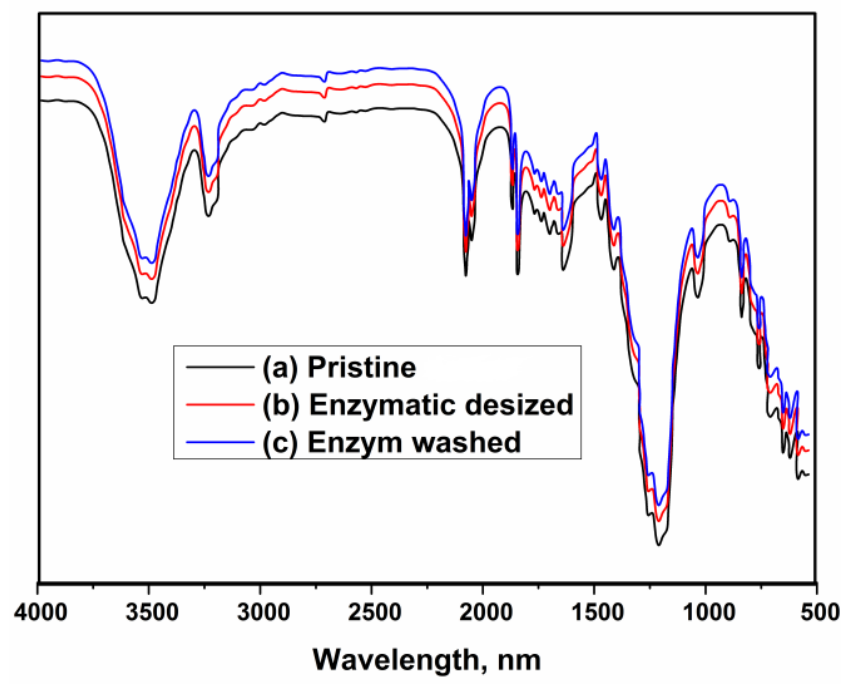

Figure 2. FT-IR spectra of (d) pristine, (e) enzymatic desized and (f) enzyme washed (optimum condition: enzyme concentration $4 \%$, $\mathrm{pH} 5.1$, temperature $50^{\circ} \mathrm{C}$ )

\subsection{Crease recovery angle}

Creases are authentic as the fabric deformations based on its viscoelastic properties. This affectionate of anamorphosis not alone has abominable furnishings on the fabrics' actualization but aswell would advance to abatement in the in the fabric wear quality [21]. Since the consumers usually prefer to wear such clothing which are resist to be creased during wear, fabrics performance related to the crease recovery property is of the main importance. Figure 3 shows the crease recovery angle values of the denim fabrics. It should be acclaimed that the washing followed by the enzymatic treatment has the highest values compared with the other treatments. This is due to the swelling of cellulose fibers which decrease the cellulose binding and improve this fiber to return to its original form. That adumbrated that the fabrics become less rigid and stiff, easier to amplitude and looser in structure. This may be regarded to cellulase enzyme treatment optimize the surface properties [22].

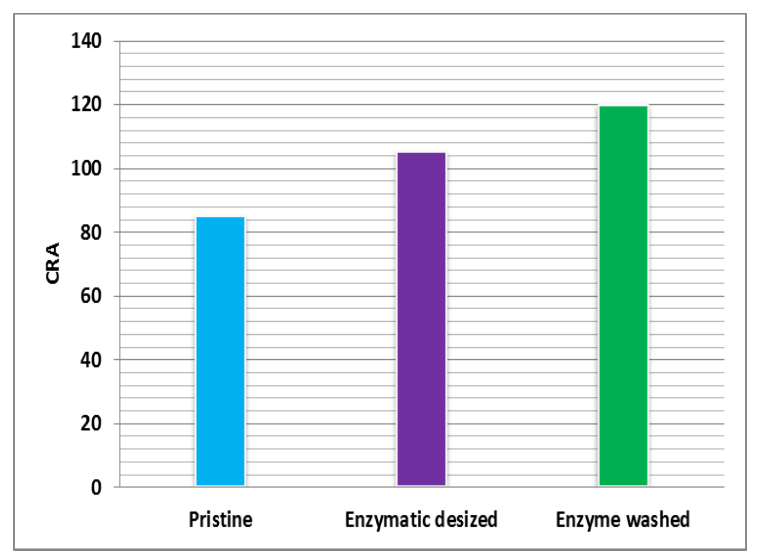

Figure 3. Crease recovery angle of (d) pristine, (e) enzymatic desized and (f) enzyme washed (optimum condition: enzyme concentration $4 \%, \mathrm{pH} 5.1$, temperature $\left.50^{\circ} \mathrm{C}\right)$

\section{Conclusion}

Biotechnology in textiles is among the progressive methods to promote fabric discipline. Consequently, our outcome awarded a potential new biotechnology with a fascinating antibacterial and appropriate UV protection residences via denim washing, situated on the use of Cellzyme. As a conclusion of this experimental study, it is determined that the healing of cellzyme on denim clothes washing may just create useful functional property in special phases by using obtaining optimum parameters like enzyme concentration- $4.0 \%$ owf (on weight of fabric), $\mathrm{pH} 5.1$ and temperature $50^{\circ} \mathrm{C}$. All these factors make them incredibly exciting from the factor of view of an industry that strives to scale down its environmental impact and to appeal to the environmentally conscious purchaser.

\section{Acknowledgement}

This work was financially supported by the China National Textile \& Apparel Council (2013 “Textile Vision" Applied Basic Research, 2013-153); Hubei Province Science and Technology Support Program (Grant No. 2013BAA043) and the Collaborative Innovation Plan of Hubei Province for Key Technology of Eco-Ramie Industry (2014-8).

\section{References}

1. D. Miller, S. Woodward, Social Anthropology. 15, 335 (2007)

2. R.M. Tyndall, Textile Chemist \& Colorist. 24, 23 (1992)

3. W. Zhao, Dyeing Finish. 34, 34 (2008)

4. N.K. Pazarlioğlu, M. Sariișik, A. Telefoncu, Process Biochemistry. 40, 767 (2005)

5. M. Sariisik, AATCC review. 4, 24 (2004)

6. Y. Yu, J. Yuan, Q. Wang, X. Fan, X. Ni, P. Wang, L. Cui, Carbohydrate polymers. 95, 675 (2013)

7. T. Bechtold, A. Turcanu, R. Campese, P. Maier, W. Schrott, Journal of Applied Electrochemistry. 36, 287 (2006)

8. M. Jucienė, V. Dobilaite, G. Kazlauskaitè, Materials Science. 12, 355 (2006)

9. C. Carr. Chemistry of the textiles industry (Springer Science \& Business Media, 1995)

10. D. Saravanan, AUTEX Research Journal. 7, 53 (2007)

11. Y. Gao, R. Cranston, Textile Research Journal. 78, 60 (2008)

12. A. Khan, M.N. Pervez, I.A. Khan, S. Ahmad, R. Masood, T. Hussain, F. Telegin, Asian Journal of Chemistry. 28, 1191 (2016)

13. D.L. Narayanan, R.N. Saladi, J.L. Fox, International journal of dermatology. 49, 978 (2010)

14. R.N. Saladi, A.N. Persaud, Drugs of Today. 41, 37 (2005)

15. C. Kan, C. Yuen, W. Wong, Journal of applied polymer science. 120, 3596 (2011) 
16. Y. Dong, Z. Bai, L. Zhang, R. Liu, T. Zhu, Journal of applied polymer science. 99, 286 (2006)

17. R. Goyal, Colourage. 52, 81 (2005)

18. M. Montazer, A.S. Maryan, Journal of applied polymer science. 110, 3121 (2008)

19. M. N. Pervez, F. Shafiq, M. M. Jilani, Z. Sarwar, Y. Cai, Material Science Forum, 893, 71, (2017).
20. J. Blakwell. ACS Symposium Series, 48, 206, (1977).

21. Y. Hassan, M. E., EL-Salmawy, A. Almetwally, Indian Textile Journal, 120, 22 (2010).

22. M.M. Eladwi, R.M. Kotb 2015. International Journal of Textile and Fashion Technology, 5, 1, (2015) 